\title{
Histopathological and Immunohistochemical studies of the effects of flaxseed in atherosclerosis of rabbits submitted to hypercholesterolemic diet with lyophilized egg to $0.5 \%$
}

\author{
Estudo Histopatológico e Imunohistoquímico dos efeitos da linhaça na aterosclerose de \\ coelhos submetidos a uma dieta hipercolesterolêmica com ovo liofilizado a $0.5 \%$
}

Estudio Histopatológico e Inmunohistoquímico de los efectos de la linaza en la aterosclerosis de conejos sometidos a una dieta hipercolesterolémica con huevo liofilizado a $0.5 \%$

Ana Flávia Champoski Mattos ${ }^{1}$, Maynara Leonardi Schuh Martins ${ }^{1 *}$, Sarah Fagundes Grobe ${ }^{1}$, Leonardo Brandão Précoma², Luiz César Guarita-Souza ${ }^{3}$, Dalton Bertolin Précoma ${ }^{3}$.

\begin{abstract}
Objective: The study aimed to evaluate the potential effects of flaxseed in atherogenesis on rabbits submitted to a hypercholesterolemic diet to $0,5 \%$ of cholesterol. Methods: The experiment lasted eight weeks and 32 male New Zealand rabbits were randomized into three groups ( $G 1=11, G 2=10$ and $G 3=11)$. All of them received, during the trial period, the diet Nuvilab ${ }^{\circledR}$ increased with $0.5 \%$ cholesterol from lyophilized egg. From the 5th to 8th week, in the G2, was added in the hypercholesterolemic diet $8 \mathrm{~g} / \mathrm{kg}$ of crushed flaxseed, totaling an average of $30 \mathrm{~g} /$ day. The same amount of crushed flaxseed was added since the beginning of the experiment to G3. Blood samples were collected in the beginning and end of the study to analyze total cholesterol, LDL-C, HDL-C and triglycerides. The euthanasia was performed on the sixty-fifth day to remove the aorta. Despite the increase in TC and LDL-C that occurred in the three experimental groups, it was statistically lower in G3. Morphometric analysis of the intima layer showed a statistically significant difference between groups $(p=0.030)$. Results: There was no statistical evidence in immunohistochemical analysis of inflammatory markers. Conclusion: The consumption of crushed flaxseed showed anti-atherogenic effects on the intimal thickening.
\end{abstract}

Keywords: Cardiovascular diseases, Functional foods, Flaxseed.

\section{RESUMO}

Objetivo: Avaliar os efeitos potenciais da linhaça na aterogênese em coelhos submetidos a uma dieta hipercolesterolêmica a $0,5 \%$ de colesterol. Métodos: $O$ experimento durou oito semanas e 32 coelhos da Nova Zelândia foram randomizados em três grupos $(\mathrm{G} 1=11, \mathrm{G} 2=10$ e G3 $=11)$. Todos eles receberam, dieta Nuvilabß com ovo liofilizado a $0,5 \%$ de colesterol. Da $5^{\text {a }}$ à $8^{\text {a }}$ semana, no G2, foi adicionado na dieta hipercolesterolêmica $8 \mathrm{~g} / \mathrm{kg}$ de linhaça triturada, totalizando uma média de $30 \mathrm{~g} / \mathrm{dia}$. A mesma quantidade de linhaça triturada foi adicionada desde o início da experiência para G3. As amostras de sangue foram coletadas no início e no final do estudo para analisar colesterol total, LDL-C, HDL-C e triglicerídeos. A eutanásia foi realizada no sexagésimo quinto dia para remover a aorta. Apesar do aumento no TC e LDL-C que ocorreu nos três grupos experimentais, foi estatisticamente menor em G3. A análise morfométrica da camada íntima mostrou diferença estatisticamente significativa entre os grupos $(p=0,030)$. Resultados: Não houve evidência estatística na análise imuno-histoquímica de marcadores inflamatórios. Conclusão: $O$ consumo de linhaça triturada mostrou efeitos anti-aterogênicos no espessamento da íntima.

Palavras-chave: Doenças cardiovasculares, Alimentos funcionais, Linhaça.

\footnotetext{
${ }^{1}$ Master - School of Medicine / Graduate Program in Health Sciences - Pontifical Catholic University of Paraná - Curitiba. *E-mail: may.schuh@gmail.com

${ }^{2}$ Medical Society Hospital Angelina Caron - Paraná - Curitiba.

${ }^{3} \mathrm{PhD}$ - School of Medicine / Health- Sciences - Pontifical Catholic University of Paraná - Curitiba.
} 


\section{RESUMEN}

Objetivo: el objetivo del estudio fue evaluar los efectos potenciales de la linaza en la aterogénesis en conejos sometidos a una dieta hipercolesterolémica al $0,5 \%$ de colesterol. Métodos: El experimento duró ocho semanas y se aleatorizaron 32 conejos de Nueva Zelanda macho en tres grupos (G1 =11, G2 = 10 y G3 = 11). Todos ellos recibieron, durante el período de prueba, la dieta Nuvilab® aumentó con $0.5 \%$ de colesterol del huevo liofilizado. De la quinta a la octava semana, en el G2, se agregaron a la dieta hipercolesterolémica $8 \mathrm{~g} / \mathrm{kg}$ de linaza triturada, con un promedio de $30 \mathrm{~g} /$ día. Se agregó la misma cantidad de semillas de lino trituradas desde el comienzo del experimento a G3. Las muestras de sangre se recolectaron al principio y al final del estudio para analizar el colesterol total, LDL-C, HDL-C y los triglicéridos. La eutanasia se realizó en el sexagésimo quinto día para extirpar la aorta. A pesar del aumento en TC y LDL-C que se produjo en los tres grupos experimentales, fue estadísticamente menor en G3. El análisis morfométrico de la capa íntima mostró una diferencia estadísticamente significativa entre los grupos $(p=0,030)$. Resultados: No hubo evidencia estadística en el análisis inmunohistoquímico de marcadores inflamatorios. Conclusión: El consumo de linaza triturada mostró efectos antiaterogénicos sobre el engrosamiento de la íntima. Palabras clave: Enfermedades cardiovasculares, Alimentos funcionales, Linaza.

\section{INTRODUCTION}

Cardiovascular diseases (CVDs) are responsible for the main causes of death in the world. In Brazil, the CVDs cause $31.25 \%$ of all deaths and according to the World Health Organization (WHO), increased morbidity and mortality tends to persist. According to data from the Brazilian Society of Cardiology in 2017, Brazil presented a record in deaths due to cardiovascular diseases, with approximately 385 thousand deaths.

Atherosclerosis is a major CVDs and it develops itself slowly over the decades and it occurs due to the exposure to risk factors such as dyslipidemia, smoking, hypertension, mellitus diabetes, obesity and emotional stress (SCHOENHAGEN and TUZCU, 2008; CASTRO and OLIVEIRA, 2009). Ignatowski's (1908); was the first to use egg yolk for the induction of atherosclerotic lesions. This was done with a group of rabbits fed with meat and another with milk and egg yolk. Both groups demonstrated the formation of atherosclerosis (DORNAS et al., 2010). Prasad (1997); carried out a study with rabbits similar to ours and observed that the oral intake of $7.5 \mathrm{~g} / \mathrm{kg}$ of linseed daily with a cholesterol diet at $1 \%$ of cholesterol increased the serum cholesterol level, confirming that this concentration really is hyperlipidemic

Studies in experimental models and even clinical trials have shown that the use of functional foods could be an alternative in the prevention and treatment of CVDs, since many kinds of foods with nutraceutical properties have been considered as preventives of atherosclerotic lesions and other cardiovascular disease. (BLOEDON and SZAPARY, 2004; HASLER et al., 2004)

Nevertheless, flaxseed, which is widely used in Brazil, is considered a functional food because in addition to their basic nutritional properties, it also has cardio-preventive properties. The bioactive compounds like alpha-linoleic fatty acid (omega-3), lignan, and fibers, are responsible for the cardio-protective effects (BLOEDON and SZAPARY, 2004). Studies have reported that the reduction in plasma levels of TC and LDL$C$ ranges from 5 to $15 \%$, according to an amount of omega-3 consumed (KRIS-ENTHERTON et al., 2002; JENKIS et al., 2002). In a study with four weeks of consumption of $50 \mathrm{~g} /$ day of flaxseed per patient, it reduced serum total cholesterol by $9 \%$ and LDL-C by $18 \%$ (CUNNANE et al., 1993). In a similar study by the same author with the same dose the reduction was $8 \%$ of LDL-C13. Prasad (1998) reports that studies with flax seed correlate benefits to various diseases such as cancer, diabetes mellitus, lupus, bone loss, liver, kidney and especially cardiovascular diseases. The CVDs increase mainly due to the high levels of total cholesterol and LDL-C in the body and the flaxseed have shown improvement in the lipid profile of the blood, acting in the prevention of atherosclerosis (DUPASQUIER et al., 200; LUCAS., et al 2011).

The rational and the importance of the subject makes flaxseed the most widely used seed in Brazil, but still needs further studies to demonstrate the benefits in the prevention and treatment of atherosclerosis.

The objective of this study was to evaluate the potential effects of flaxseed in the prevention and treatment of atherogenesis in rabbits submitted to a hypercholesterolemic diet with $0.5 \%$ of lyophilized egg. 


\section{METHODS}

\section{Animals}

The experimental study was conducted after the approval by the Ethics Committee in research using animals (CEUA), of PUCPR, under protocol number 449/2010. The calculation of the sample size was based on Prim et al. (2012) study. The animals (32 rabbits) were randomized into three groups, with one animal per cage, according to the pre-established dietary treatment for eight weeks. The animals started the study with approximately $1500 \mathrm{~g}$, with a mean age of four months.

The group G1 (eleven animals) on the eight weeks of the experiment received the standard food for rabbits - Rabbits Nuvilab (Nuvital, Colombo / PR) - added with $0.5 \%$ of cholesterol from lyophilized egg. The G2 (ten animals) received on the first four weeks the same standard food with an increase of $0.5 \%$ cholesterol from the lyophilized egg and from the fifth to the eighth week it was added a hypercholesterolemic diet $8 \mathrm{~g} / \mathrm{kg} / \mathrm{rabbit}$ weight of crushed flaxseed.

Figure 1. Experimental design of the study

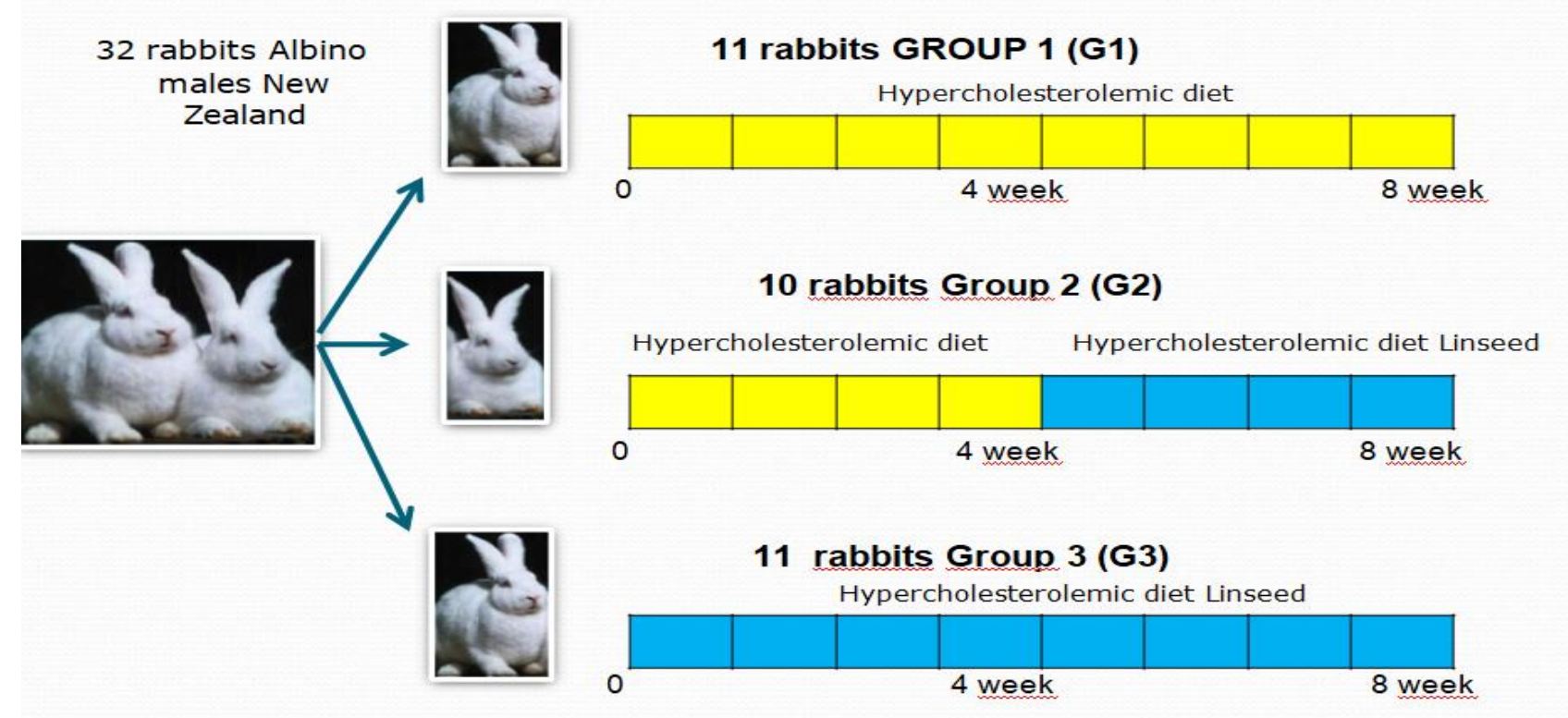

Source: Research data, 2018

The G3 (eleven animals) received on the eight weeks of the experiment standard food for rabbits with $0.5 \%$ cholesterol from lyophilized egg and $8 \mathrm{~g} / \mathrm{kg} / \mathrm{rabbit}$ weight of crushed flaxseed (G1). The average flaxseed supplied to each rabbit (G2 and G3) per day was approximately $30 \mathrm{~g}$. The addition of lyophilized egg was used in other studies for the induction and formation of atherosclerotic lesions. This study used $0.5 \%$ of lyophilized egg in the food of the rabbits. 


\section{Blood collection}

Biological blood samples from each rabbit for biochemical analysis were collected to analyze: total cholesterol (TC), low density lipoprotein (LDL), high density lipoprotein (HDL-C) and triglycerides (TG). The animals were anesthetized with xylazine (Coopazine® Coopers, $5 \mathrm{mg} / \mathrm{kg}$ ) and ketamine (Vetanarcol®-König, $30 \mathrm{mg} / \mathrm{kg}$ ) intramuscularly in the thigh region. The collect was performed by cardiac puncture at time zero of the study and the preoperative period (euthanasia), following a fasting for 12 hours before the examination.

\section{Histological analysis}

The arteries were removed, washed and attached with $10 \%$ formaldehyde buffered with phosphate $(\mathrm{pH}=$ 7.6) for 10 minutes and embedded in paraffin. After repair of the arteries, the animals were euthanized with a lethal dose of barbiturate - sodium thiopental (Thionembutal( ${ }^{\circledR}$ ), according to RDC No. 714 (2002). The paraffin blocks were cut into microtome (RM2145 Leica $\AA$ ) and the obtained blades were stained with hematoxylineosin for carrying out qualitative and quantitative histological analyzes, orceine (elastic) to morphometry and labeled with specific antibodies for immunohistochemistry. The atherosclerotic lesions found in the macroscopic study (in all sections) were visibly graded using a scale from 0 to $\mathrm{VI}$, according to the qualitative criteria proposed by Stary et al. (1992). Morphometric measurements were performed on blades stained with orcein (elastic) in order to determine the area of the intima and media layers of the aorta of three groups of rabbits, using Image Pro-plus to v.4,5 Windows, the microscope Olympus BX50 and Sony ${ }^{\circledR}$ camcorder, using the application called morphometry "line", previously calibrated in micrometers with the 20 times objective. The measures were transferred and analyzed in Excel for Windows ${ }^{\circledR}$.

\section{Immunohistochemistry}

The ICAM monoclonal antibodies (CD54-ICAM-1®, Novocastra Laboratories), VCAM (CD106-VCAM-1®, Novocastra Laboratories) and IL-6 (IL-IW-2005-6®, Imuny Biotechnology) were analyzed on dilutions of microliters 1:50, 1:100 microliters to 1:400 microliters, respectively for 1 hour; and MCP-1 polyclonal antibody (IP-1023-MCP-1®, Imuny Biotechnology) were diluted to 1:400 microliters. For quantitative analysis, the images of aortas were scanned from each animal and divided into four fields.

The blade reading was performed with Image Pro-plus v. 4.5 for Windows ${ }^{\circledR}$ using the application "area". Positive areas for the antibodies were stained brown and negative with blue color, characterizing thereby, using the method of color morphology. For each tag a photo was chosen in order to be used as a mask, to quantify the positive areas as well. The measures were transferred and analyzed in Excel for Windows.

\section{Statistical analysis}

The results were described as mean, median, minimum and maximum values, and standard deviations. To compare the groups regarding to quantitative variables that met the normal condition, it was considered the Analysis of Variance (ANOVA) with a factor and LSD test (least significant difference) for multiple comparisons. For variables that did not meet the normal condition, it used the nonparametric Kruskal-Wallis. The comparison between the two assessments (initial and final), within each group, was made using the Student $t$ test for paired samples. The normality condition was assessed by the Shapiro-Wilks test. P values $<0.05$ were considered statistically significant. Data were analyzed using the Statistics computer program v.8.0.

\section{RESULTS}

\section{Weight of Animals}

The comparative analysis of the weights of rabbits in all the groups showed that the weight gain in all groups during the experimental period was similarly, showing no significant difference at the beginning and at the end of the study. Thus, neither the diet with egg nor with flaxseed causes any significant weight change. 
Graph 1. Ponderal evolution of the animals throughout the experimental period

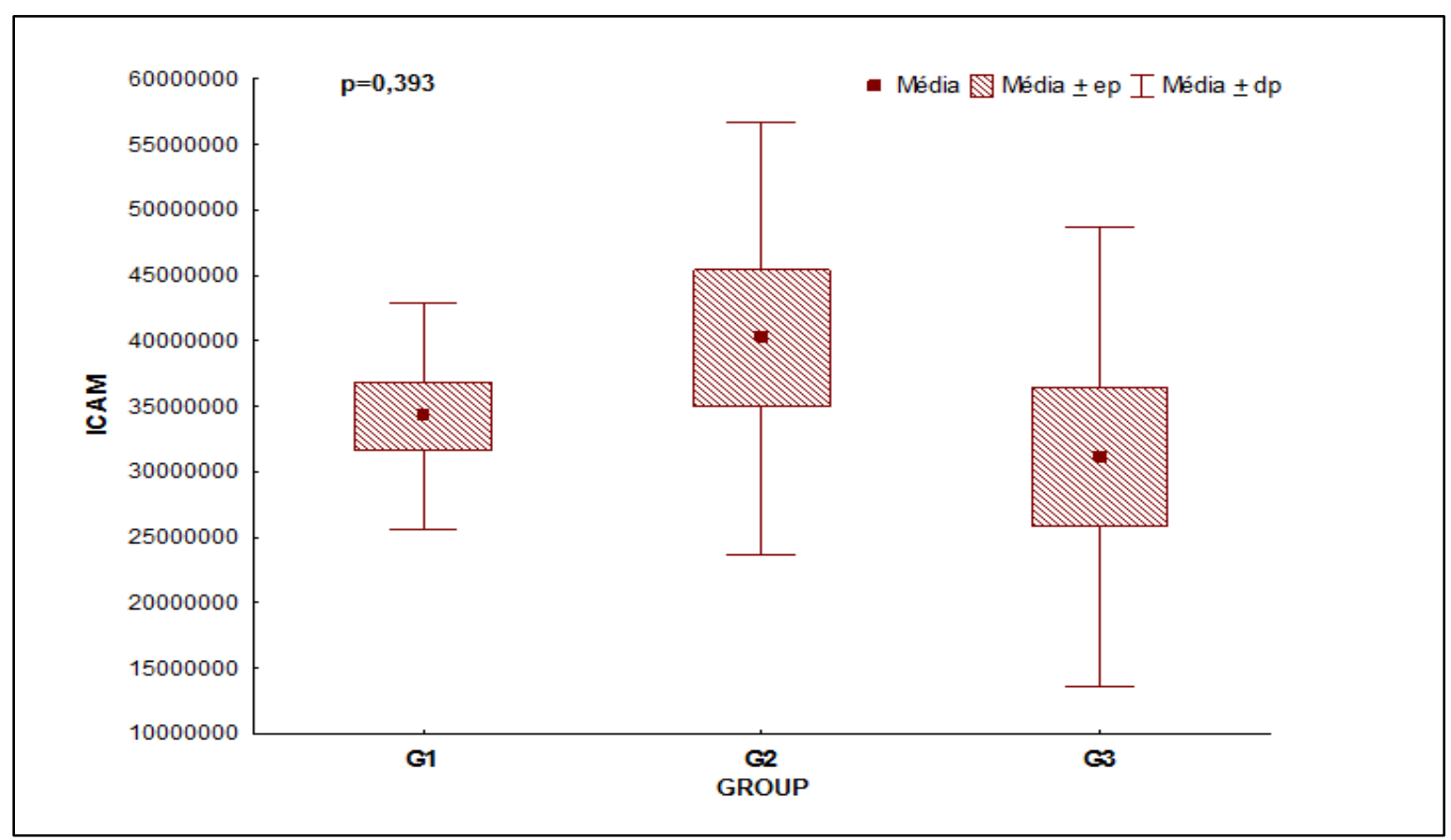

Source: Research data, 2018.

\section{Biochemical variables}

The total cholesterol values at the baseline did not differ among the groups. Nevertheless, at the end of the trial period, the increase in cholesterol occurred in all three groups and was statistically lower in the group receiving the addition of flaxseed in the diet from the beginning of the experiment. Group 3 (G3) had increased about $50 \%$ lower than that G1, and G2 less than 44\%, as can be seen in Table 1.

Table 1. Mean, median, standard deviation and $p$ value for total cholesterol ANOVA with one factor, $p<0.05$.

\begin{tabular}{|c|c|c|c|c|c|}
\hline Variable & Group & $\mathbf{n}$ & $\begin{array}{l}\text { Média } \\
\text { (mg/dl) }\end{array}$ & $\begin{array}{l}\text { Standard } \\
\text { deviation }\end{array}$ & $\begin{array}{c}\text { Value de } \\
p \\
(G 1 \times G 2 \\
\times \text { G3) }\end{array}$ \\
\hline \multirow{3}{*}{$\begin{array}{c}\text { Total cholesterol - } \\
\text { initial }\end{array}$} & G1 & 11 & 75,8 & 36,7 & \multirow{3}{*}{0,442} \\
\hline & G2 & 10 & 73,5 & 25,3 & \\
\hline & G3 & 11 & 61,7 & 14,9 & \\
\hline \multirow{3}{*}{$\begin{array}{c}\text { Total cholesterol - } \\
\text { Final }\end{array}$} & G1 & 11 & 642,3 & 392,4 & \multirow{3}{*}{0,009} \\
\hline & G2 & 10 & 731,6 & 258,9 & \\
\hline & G3 & 11 & 321,7 & 215,3 & \\
\hline \multirow{3}{*}{$\begin{array}{l}\text { Difference (end - } \\
\text { initial) }\end{array}$} & G1 & 11 & 566,5 & 372,7 & \multirow{3}{*}{0,009} \\
\hline & G2 & 10 & 658,1 & 250,4 & \\
\hline & G3 & 11 & 260,0 & 208,6 & \\
\hline
\end{tabular}

Source: Research data, 2018. 
Similar results were observed for LDL-C levels. There was an increase in serum LDL-C levels in both groups after the experimental period. However, when we analyze the difference between initial and final between the groups, in G3 this difference was $281.1 \mathrm{mg} / \mathrm{dl}$, while in $\mathrm{G} 1$ was $570.6 \mathrm{md} / \mathrm{dl}$ and G2 $664.2 \mathrm{mg} / \mathrm{dl}$. As well as the total cholesterol, unlike LDL-C final and the difference (end-start) is among G1xG3 and G2xG3. The difference in LDL-C final between G1xG3 decreased by $48 \%$ and G2xG3, 42\% reduction. The difference between initial and final found between G1xG3 G2xG3 and showed a reduction of $49 \%$ and $42 \%$, respectively.

Table 2. Mean, median, standard deviation and $p$ value for LDL- cholesterol ANOVA with one factor, $p<0.05$.

\begin{tabular}{cccccc}
\hline Variable & Group & $\mathbf{n}$ & $\begin{array}{c}\text { Média } \\
\text { (mg/dl) }\end{array}$ & $\begin{array}{c}\text { Standard } \\
\text { deviation }\end{array}$ & $\begin{array}{c}\text { Value de p } \\
(\mathbf{G 1} \text { x G2 x G3) }\end{array}$ \\
\hline \multirow{3}{*}{ LDL- initial } & G1 & 11 & 34,8 & 33,7 & \\
& G2 & 10 & 30,6 & 21,7 & 0,085 \\
& G3 & 11 & 12,8 & 6,6 & \\
\hline \multirow{2}{*}{ LDL-Final } & G1 & 11 & 605,4 & 390,1 & \\
& G2 & 10 & 694,8 & 255,1 & 0,010 \\
& G3 & 11 & 294,0 & 211,4 & \\
$\begin{array}{c}\text { Difference (end - } \\
\text { initial) }\end{array}$ & G1 & 11 & 570,6 & 370,2 & \\
\hline
\end{tabular}

Source: Research data, 2018.

As for HDL-C, it can be seen that in G3 this lipoprotein was reduced by approximately $35 \%$, compared to $\mathrm{G} 1$ at the end of the experimental period, about its own initial value.

Table 3. Mean, median, standard deviation and $p$ value for HDL- cholesterol ANOVA with one factor, $p<0.05$.

\begin{tabular}{cccccc}
\hline Variable & Group & $\mathbf{n}$ & $\begin{array}{c}\text { Média } \\
\text { (mg/d) }\end{array}$ & $\begin{array}{c}\text { Standard } \\
\text { deviation }\end{array}$ & $\begin{array}{c}\text { Value de } \mathbf{p} \\
\text { (G1 x G2 x G3) }\end{array}$ \\
\hline \multirow{3}{*}{ HDL - initial } & G1 & 11 & 21,3 & 9,3 & \\
& G2 & 10 & 20,3 & 4,7 & 0,381 \\
& G3 & 11 & 24,4 & 5,8 & \\
\hline \multirow{3}{*}{ HDL-Final } & G1 & 11 & 23,7 & 8,8 & \\
& G2 & 10 & 19,1 & 4,6 & $\mathbf{0 , 0 1 0}$ \\
& G3 & 11 & 15,0 & 3,8 & \\
\multirow{2}{*}{$\begin{array}{c}\text { Difference (end - } \\
\text { initial) }\end{array}$} & G1 & 11 & 2,5 & 11,7 & \\
\hline
\end{tabular}

Source: Research data, 2018 
For triglycerides, there was a decrease in all the groups between the values of the end and the beginning of the experiment, but there was no statistical difference. However, when compared to the initial and final average within each group, we found a significant reduction of approximately $60 \%$ on G3.

Table 3. Mean, median, standard deviation and $p$ value for HDL- cholesterol ANOVA with one factor, $\mathrm{p}<0.05$.

\begin{tabular}{cccccc}
\hline Variable & Group & $\mathbf{n}$ & $\begin{array}{c}\text { Média } \\
\text { (mg/dl) }\end{array}$ & $\begin{array}{c}\text { Standard } \\
\text { deviation }\end{array}$ & $\begin{array}{c}\text { Value de p } \\
\text { (G1 } \mathbf{G} \text { G2 x }\end{array}$ \\
\hline $\begin{array}{c}\text { G3) } \\
\text { triglycerides - } \\
\text { initial }\end{array}$ & $\mathrm{G} 1$ & 11 & 98,5 & 40,6 & \\
& $\mathrm{G} 2$ & 10 & 112,2 & 31,2 & 0,050 \\
& $\mathrm{G} 3$ & 11 & 161,0 & 88,1 & \\
$\begin{array}{c}\text { triglycerides- } \\
\text { Final }\end{array}$ & $\mathrm{G} 1$ & 11 & 65,6 & 26,2 & \\
& $\mathrm{G} 2$ & 10 & 88,5 & 37,3 & 0,166 \\
$\begin{array}{c}\text { Difference (end - } \\
\text { initial) }\end{array}$ & $\mathrm{G} 3$ & 11 & 63,8 & 31,9 & \\
\hline
\end{tabular}

Source: Research data, 2018

\section{Histological analysis}

By histological analysis the degree of atherosclerotic lesions present in the aortas of rabbits in the three groups were evaluated. All sections from each aorta's rabbits were analyzed. It was possible to find each aortic atherosclerotic load, i.e. verify the most frequent lesion degree of each rabbit. Grade III lesions were found, but most of the animals had grade I atherosclerotic lesions. In Figure 01, an example of how the development of intimal thickening in the three groups occurred can be seen.

Figure 01 - Atherosclerotic lesions developed in the aortas of rabbits treated with commercial food added with $0.5 \%$ of lyophilized egg. The black line indicates the thickness of the intima. $A=$ Group 1 , the presence of severe intimal thickening; $B=$ Group 2, early intimal thickening; and $C=$ Group 3, absence of intimal thickening. $\mathrm{L}=$ lumen of the vessel. (Objective 20x).

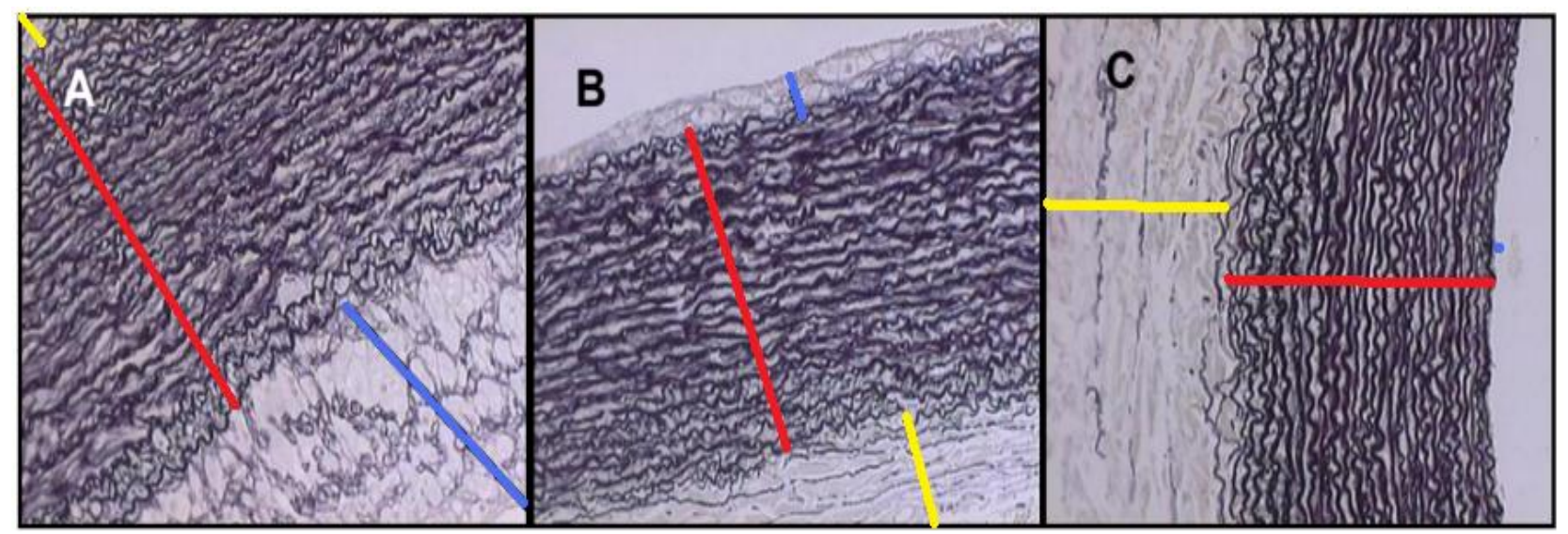

Source: Research data, 2018 


\section{Morphometric analysis}

There was no statistically significant difference in the thickness of the average layers between the groups. However, there were statistically significant differences found in the thickness of the inner layer of the analyzed aortas on $\mathrm{G} 1$ and $\mathrm{G} 3(\mathrm{p}=0.034)$ with a reduction of $67 \%$, and between $\mathrm{G} 2$ and $\mathrm{G} 3(\mathrm{p}=0.011)$ with $54 \%$ reduction.

Table 4. Mean, median, standard deviation and $p$-value for morphometric analysis ANOVA with one factor, $p<0.05$.

\begin{tabular}{ccccccc}
\hline Variable & Group & $\mathbf{n}$ & $\begin{array}{c}\text { Média } \\
\text { (mg/d) }\end{array}$ & Median & $\begin{array}{c}\text { Standard } \\
\text { deviation }\end{array}$ & Value de $\mathbf{p}$ \\
\hline $\begin{array}{c}\text { Intimate } \\
\text { layer }\end{array}$ & G1 & 11 & 46,2 & 13,2 & 68,4 & \\
thickness & G3 & 11 & 32,3 & 17,5 & 32,4 & $\mathbf{0 , 0 3 0}^{*}$ \\
\hline $\begin{array}{c}\text { Thickness } \\
\text { middle }\end{array}$ & G1 & 11 & 292,2 & 286,7 & 46,5 & \\
$\begin{array}{c}\text { layer } \\
\text { Gayer }\end{array}$ & G3 & 10 & 274,9 & 269,3 & 49,0 & $0,327^{\star *}$ \\
\hline
\end{tabular}

Source: Research data, 2018.

\section{Immunohistochemistry analysis}

The analysis of the positive areas for vascular cell adhesion molecule (VCAM-1) for intercellular adhesion molecules (ICAM-1) to interleukin-6 (IL-6) and for chemo attractant protein-1 monocytes (MCP -1) did not show statistically significant differences in the aortas in all the groups.

Graph 2. Mean, median, standard deviation and $p$-value for ICAM analysis ANOVA with one factor, $p<0.05$.

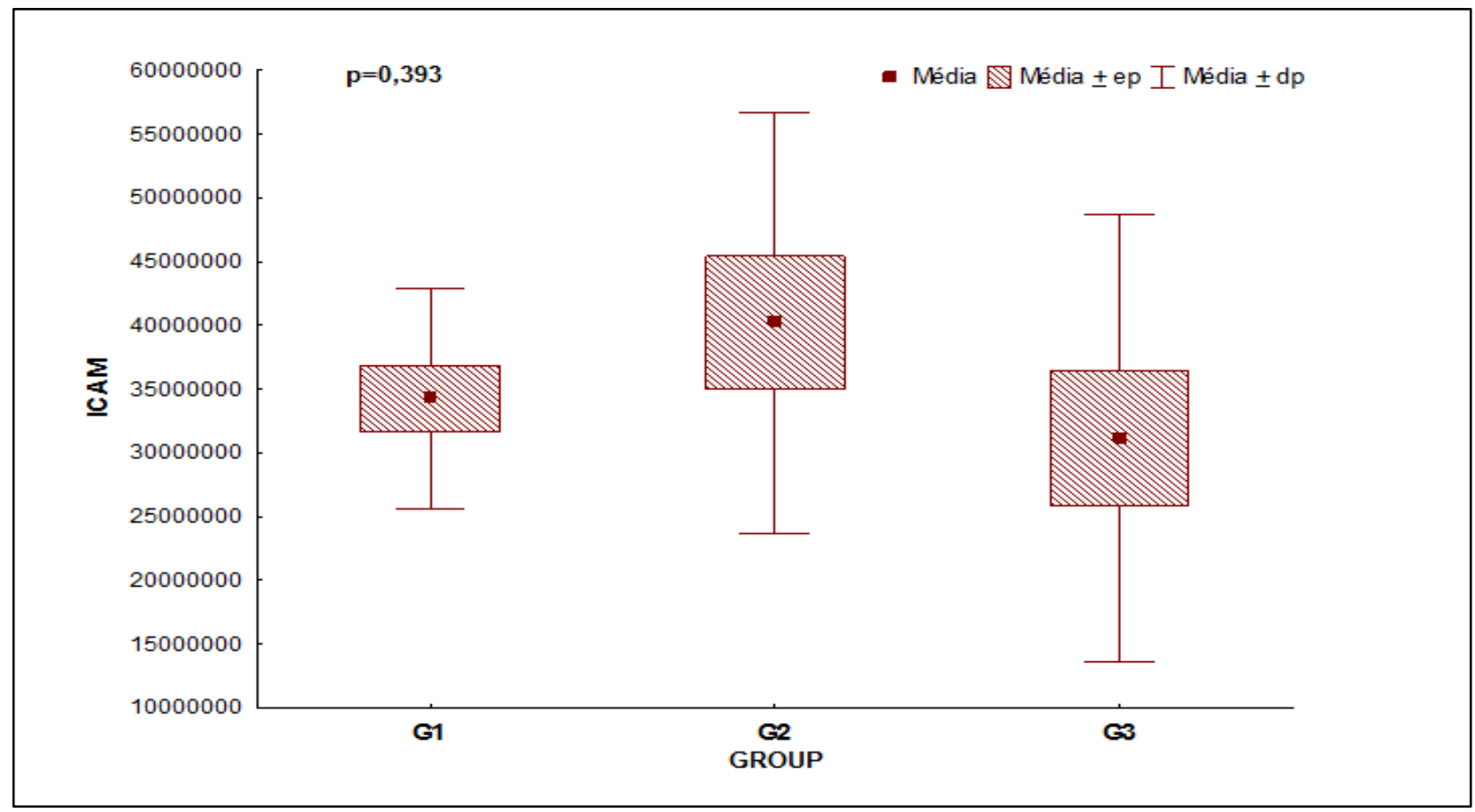

Source: Research data, 2018. 
Graph 3. Mean, median, standard deviation and $p$-value for VCAM analysis ANOVA with one factor, $p<0.05$.

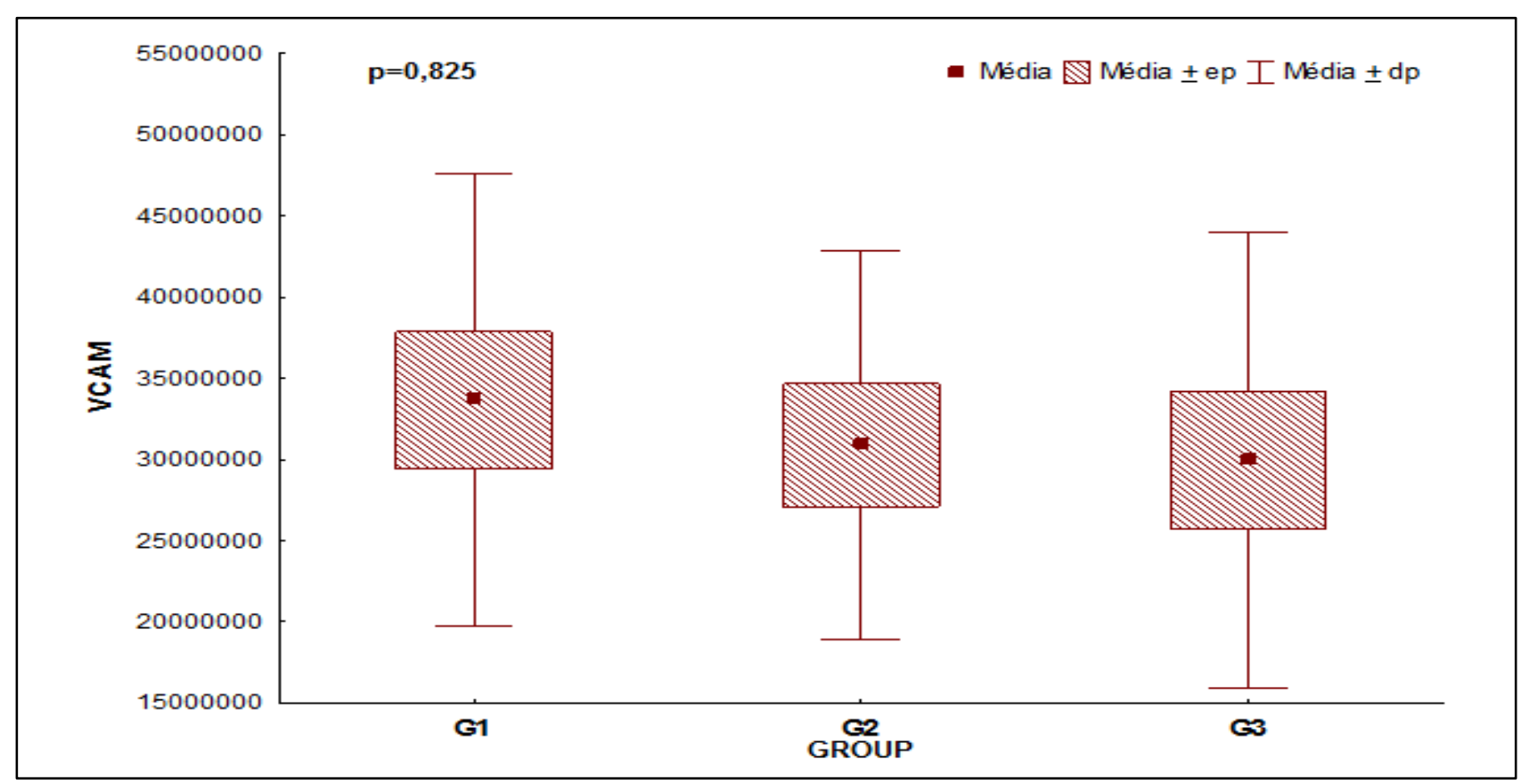

Source: Research data, 2018.

Graph 4. Mean, median, standard deviation and $p$-value for interleukin-6analysis ANOVA with one factor, $p$ $<0.05$.

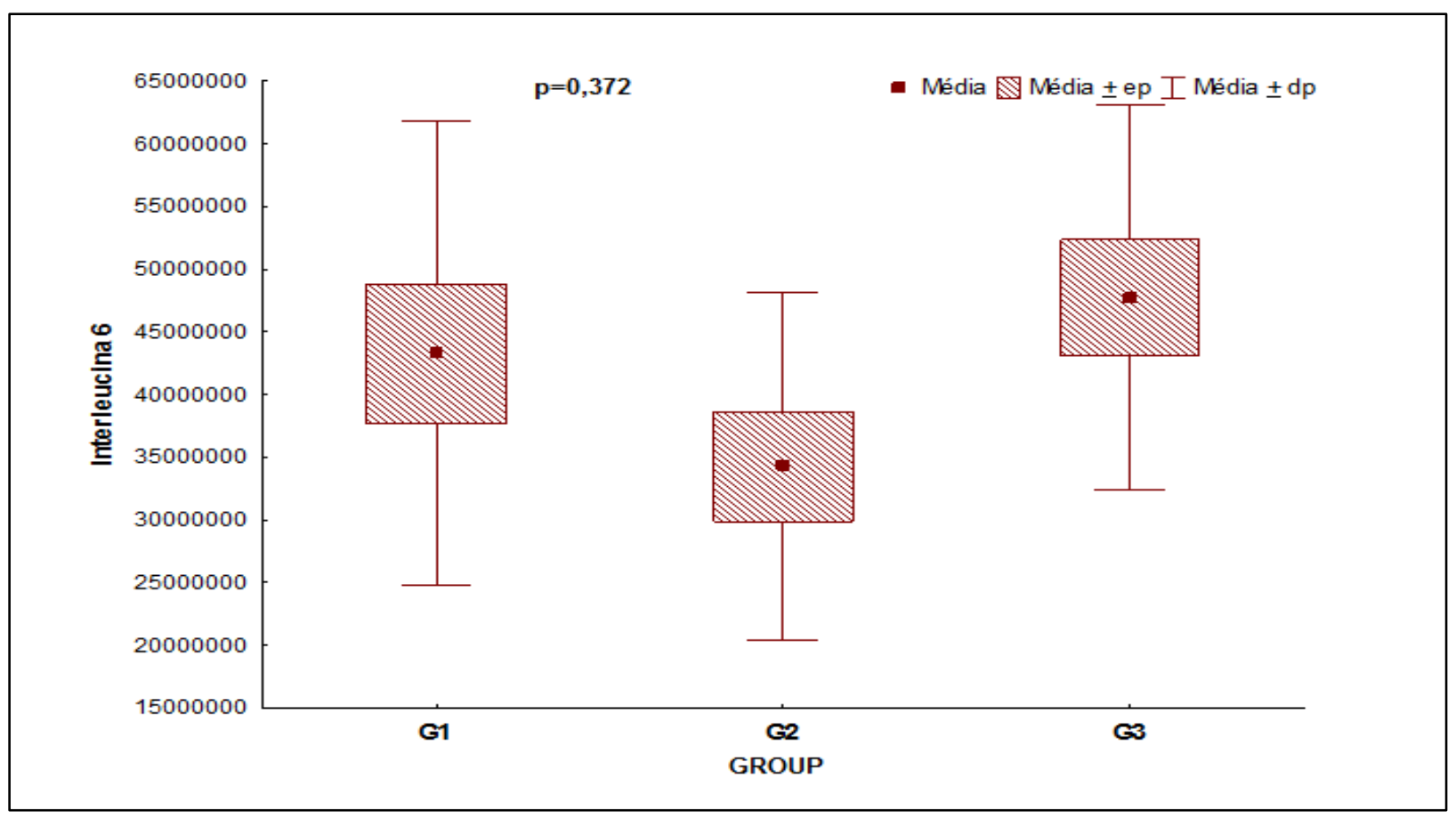

Source: Research data, 2018. 
Graph 5. Mean, median, standard deviation and p-value for MCP 1 analysis ANOVA with one factor, $p$ $<0.05$.

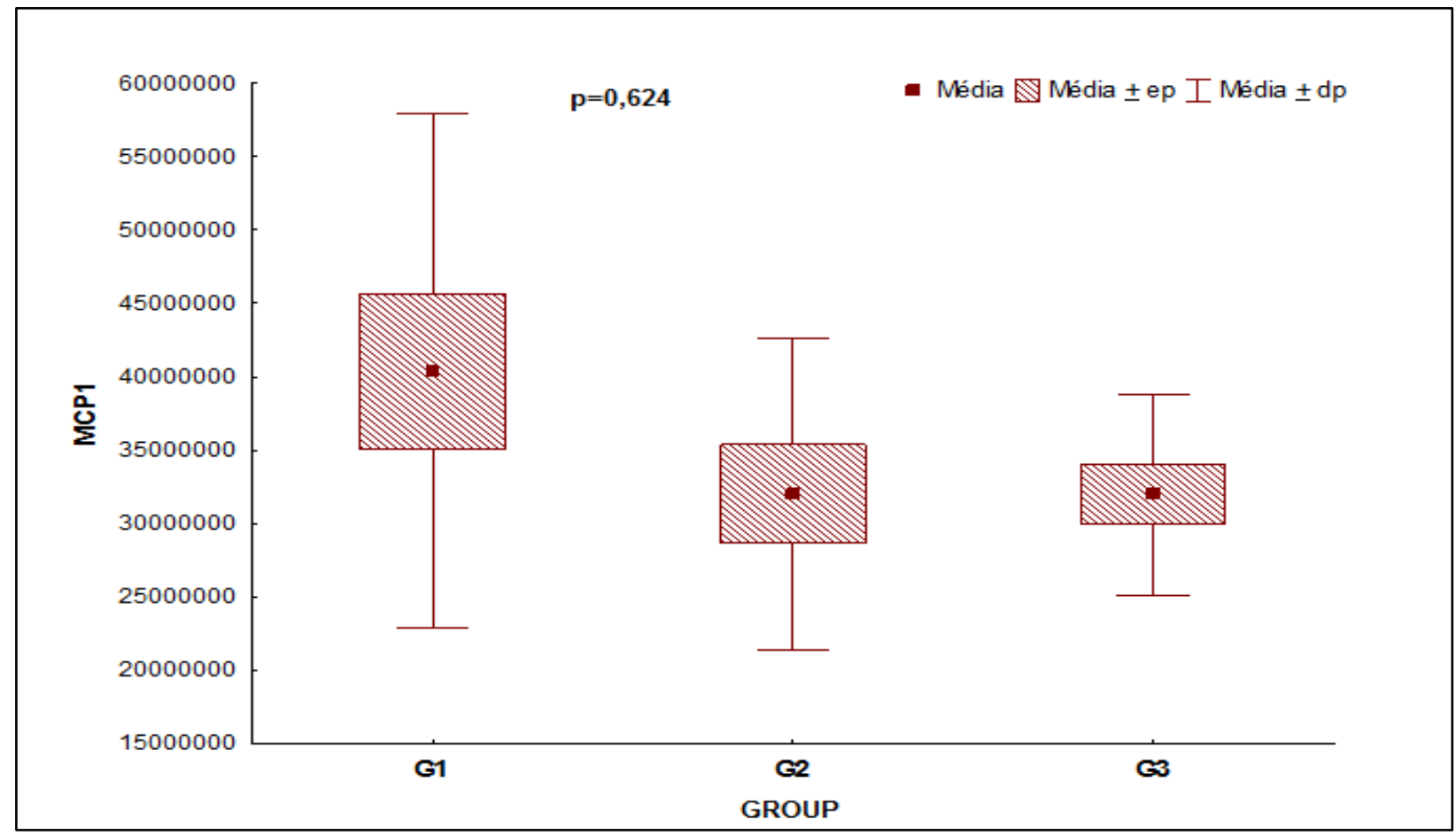

Source: Research data, 2018.

Figure 02. Demonstrates the marcapéuticos in the immunohistochemical analyzes in the arteries of the rabbits submitted to a diet Group $1.1=\mathrm{ICAM} ; 2=\mathrm{VCAM} ; 3=\mathrm{IL}-6 ; 4 \mathrm{MCP}=1$.

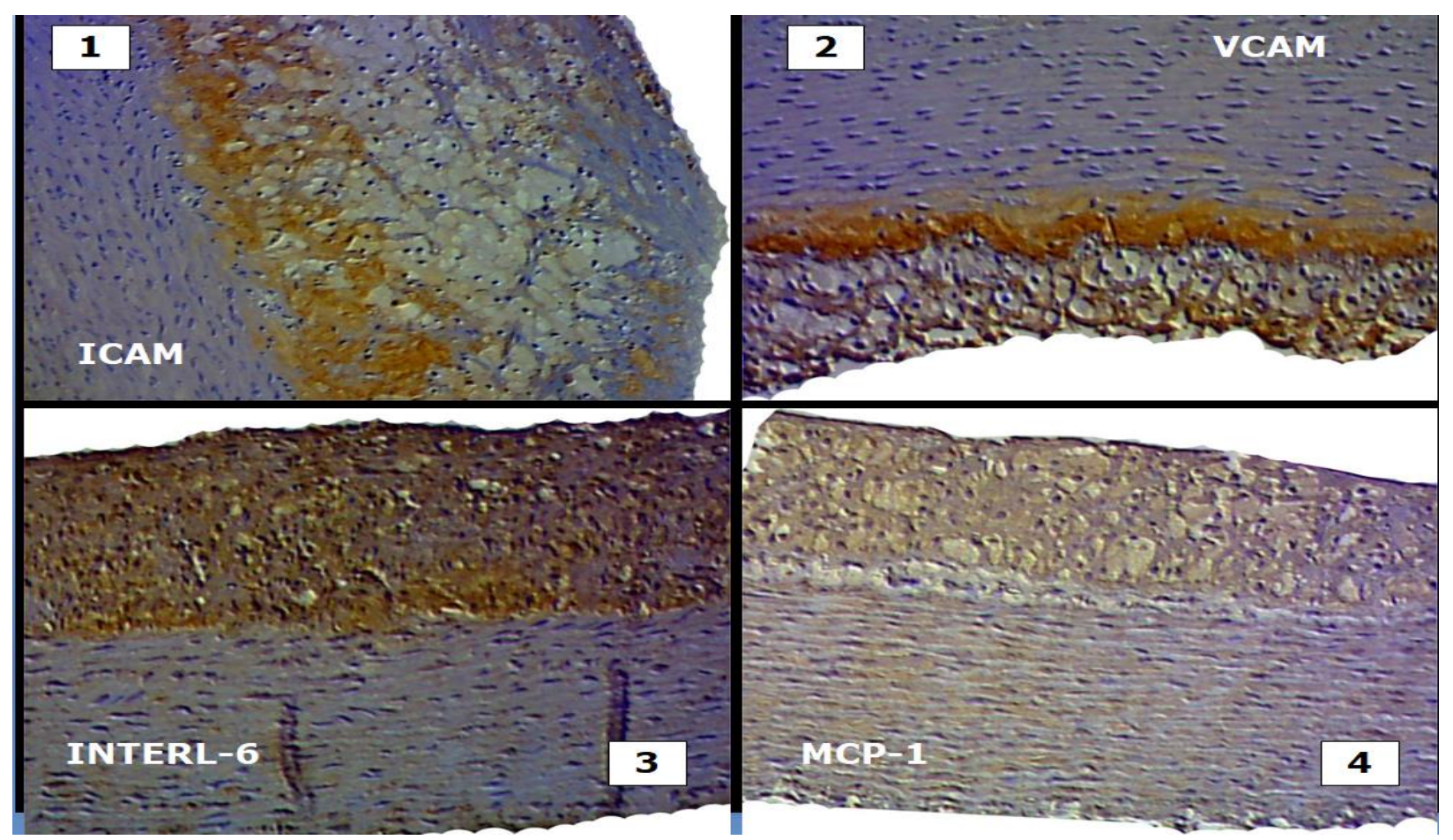

Source: Research data, 2018 


\section{DISCUSSION}

Rabbits are sensitive animals to high cholesterol diets, accumulating easily large amounts in their body. For this reason, its use is an ideal experimental model (DORNAS et al., 2010). Among the ways to promote and develop hypercholesterolemia injuries are the uses of foods rich in fats and cholesterol (BAYINDIR et al., 2002; BRONSGEEST-SCHOUTE et al., 1979)

The addition of lyophilised egg has been used in other studies for the induction and formation of atherosclerotic lesions. In this protocol, $0.5 \%$ of lyophilized egg was used, which proved to be effective in the formation of atherosclerotic lesions during the experimental time used, which were 8 weeks.

The amount of cholesterol added to the diet directly influences the levels of cholesterolemia. Jaldin et al. (2006) demonstrated that addition of $0.15 \%$ of cholesterol from egg yolk, developed mild atherosclerosis in rabbits that underwent the study. Study with the addition of $1 \%$ cholesterol from lyophilized egg showed that most animals in the created atherosclerotic lesions were degree III (PRIM et al., 2012). Based on this study, we used this experimental protocol the addition of $0.5 \%$ cholesterol, producing less severe injuries in animals. Thus, this protocol has proven effective in studies that require this type of injury.

The daily intake of flaxseed may vary from 15 to $50 \mathrm{~g}$ /day (KRIS-ENTHERTON et al., 2002). Studies claim that the reduction in plasma levels of TC and LDL-C ranging from 5 to 15\% (KRIS-ENTHERTON et al., 2002; JENKIS et al., 2002). A study of consumption of $50 \mathrm{~g} /$ day of flaxseed, lowered total serum cholesterol by $9 \%$ and LDL-C by $18 \%$. In other study, $10 \%$ of flaxseed did not affect lipids, but $20 \%$ and $30 \%$ flaxseed reduced plasma CT in $21 \%$ and $33 \%$ respectively, and LDL-C by $33 \%$ and $67 \%$, respectively (RATNAYAKE et al., 1992). Prasad (1999) found a $33 \%$ reduction of CT and $35 \%$ LDL-C, in a study with isolated lignan.

In this study, CT and LDL-C levels have similar results, there was an increase in serum levels in the three groups after the experimental period. The amount of cholesterol used must have been responsible for this result, as in G1, that received hypercholesterolemic diet by the lyophilized egg, an increase of eight times the initial total cholesterol occurred in the end. However, the G3 that received the addition of flaxseed throughout the experiment presented a final plasma concentration of TC and LDL-C at lower levels. Occurring therefore increased attenuation in both CT and for LDL-C compared to the other groups. These data show that despite the hypercholesterolemic diet was offered in G3, flaxseed acted preventing TC and LDL-C to increase as in the other groups.

As this study, Lucas et al., (2004) reported that the prevention of the increase in TC was effective at three different concentrations of flaxseed. However, there are various results in the literature. Study of diet in rabbits $10 \%$ flaxseed also had no effect on cholesterol total (DUPASQUIER et al., 2006). A study of 15 healthy men, consuming three daily cakes containing $32.7 \mathrm{~g}$ of total flaxseed for four weeks resulted in unaltered TC and LDL-C (STUGLIN and PRASAD, 2005). These conflicting results may be due to several factors such as: amount of ingested cholesterol; used amount of flaxseed or its components; the way they were administered (whole or crushed); form of preparation (subject to temperature changes or otherwise) and the concentration of seed consumption.

When we analyze the HDL-C of this study, it was observed that on G3 there was a $35 \%$ reduction of this lipoprotein. Similar results were performed by Mandasescu et al (2005), which founded a $33.5 \%$ decrease in $\mathrm{HDL}-\mathrm{C}$ in hyperlipidemic subjects consumed $20 \mathrm{~g} /$ day of flaxseed for two months. There is evidence indicating that dietary unsaturated fatty acids may alter plasma levels HDL-C27. A study in humans showed that HDL-C was lowered in individuals consuming a diet rich in polyunsaturated fatty acids compared to a diet rich in saturated fatty acids (RALOVA et al., 2008). This may be an explanation for the reduction of HDL-C by G3, since the flaxseed has a large amount of omega-3, a polyunsaturated fatty acid. However, more studies are needed to assess the effects of polyunsaturated fatty acids in HDL-C, using a saturated fatty acid as a reference for comparison.

Additionally, ATP-binding cassette transporter A1 (ABCA1) is a transporter that plays a critical role in the formation and HDL-C metabolism. In vitro studies indicate that unsaturated fatty acids reduce the expression 
of $A B C A 1$ in transcript levels. Thus, the decreased expression of $A B C A 1$ by polyunsaturated fatty acids could also explain the decrease in HDL-C observed in this study (LEE et al., 2012).

Regarding triglyceride levels, the amount of flaxseed used in this experimental protocol was effective to promote the reduction when compared to the average starting and ending within each group, showing significant difference mainly in the group G3.

A similar result observed by Marques et al. (2011) showed that flaxseed consumption reduced serum triglyceride levels. In other study, the use of $10 \%$ of flaxseed in the diet did not affect serum lipids, but $20 \%$ and $30 \%$ reduced triglycerides by $23 \%$ in both concentrations (RATNAYAKE et al., 1992). Dupasquier et al. (2006) studied rabbits with a diet of $10 \%$ flaxseed and observed a decrease in atherosclerotic lesions and reduction of triglycerides.

In this study, a use of hypercholesterolemic diet with $0.5 \%$ lyophilized egg observed, by morphometric analysis, the development of atherosclerotic lesions in all groups, founding mostly grade I lesions. Prim et al. (2012) using a hypercholesterolemic diet with $1 \%$ lyophilised egg, saw grade III atherosclerotic lesion in most animals. This should be a reflection of cholesterol dose that had been used. Thus, we concluded that even by using a diet with a lower amount of cholesterol, the lesion development can still be observed in a short period of time. So, this model resulted suitable for the proposed studies.

All the aortas were analyzed and it's respectively cuts and was observed the difference between the groups regarding the thickness of the intima. When comparing the values of $\mathrm{G} 1$ with others, we found that there was a significant difference with the G3, showing that flaxseed served in preventing the formation of lesions. However, we cannot say that it acts in regression or in advance of the atherosclerotic process, since there was no statistically significant difference between $\mathrm{G} 1$ and $\mathrm{G} 2$.

Lucas et al. (2004) also found decreased intimal thickening, reducing injuries in oophorectomized hamsters fed with flaxseed. Prasad (1999) found a reduction of atherosclerosis in $73 \%$ of the aortas of rabbits fed with hypercholesterolemic diet and an isolated lignin from the flaxseed. In a review study, Prasad (2009) shows that flaxseed, low linolenic acid flaxseed, lignans, flaxseed complex and isolated lignan were also effective in reducing the development of atherosclerosis in rabbits, but had no effect on the regression of the lesion; the same as observed in our study.

Prasad (1997) study with rabbits with a cholesterol diet of $1 \%$ reduced the development of aortic atherosclerosis by $46 \%$.

Inflammation in atherosclerosis occurred, allows the use of markers involved in this process. We evaluated the presence of four markers, two of cell adhesion molecules (VCAM-1 and ICAM-1), a cytokine (IL-6) and chemokine (MCP-1) - one chemotactic factor for monocytes.

To perform immunohistochemical analysis, it was chosen the cutting with a higher degree of injury for each rabbit studied and the results showed no statistically significant differences for any of the four evaluated markers. Thus, we can conclude that flaxseed was not able to alter the expression of these markers.

When we look at the immunohistochemical analysis results of Prim et al. (2012), we note that the data are similar to our study for VCAM-1 and ICAM-1 markers, because in this study there were also no differences between the groups.

We can observe the anti-inflammatory effects of linolenic acid (ALA) in studies such as the Duspaquier et al. (2007), who reported that the diet supplemented with flaxseed reduced macrophage infiltration into the subendothelial space, as well as the synthesis of VCAM-1 and IL-6 in the aortic tissue of animals, with no significant change in the levels of these markers in normocholesterolemic animals. In the study by Zhao et al. (2004) hypercholesterolemic patients received six weeks flaxseed oil, and obtained a reduction in serum levels of VCAM-1 and ICAM-1. Instead, Prasad (2009) concluded that only when the intake is greater than $14 \mathrm{~g}$ is greater reduction in markers inflamatórios. 
Most studies showed anti-inflammatory effect of flaxseed and its components. However, the observed different results may be due to different methodologies, especially regarding the amount of cholesterol in the diet offered and the period of the studies.

It is possible that the results for the immunohistochemistry of our study have not presented statistical difference due to the choice of only one cut (higher degree of injury) to perform the analyzes. This hypothesis explains the difference in the results of morphometry and immunohistochemistry in this study because there was difference in the morphometry, which analyzed all cuts of all the aortas. Therefore, more studies should be done so that you can check the anti-inflammatory effect of flaxseed.

\section{Study limitations}

We understand the importance of performing immunohistochemical analysis on a greater number of cuts, possibly setting anatomically analysis of some cuts without choosing exactly what has the greatest degree of injury. Another issue is the time of the study that could influence the results. Another point to be highlighted is that although the groups present some final characterization data, there is no presence of a control group, because the ethics committee in animal research does not allow it.

\section{CONCLUSION}

Pathological and immunohistochemical study of the aorta of rabbits submitted to a hypercholesterolemic diet $0.5 \%$ lyophilized egg showed that crushed flaxseed was not able to act as anti-inflammatory markers in the study, but showed anti-atherogenic effects on the intimal thickening.

\section{ACKNOWLEDGEMENTS}

This study was conducted with financial support Fundação Araucária. All authors read and approved the final text. The authors declare that there are no conflicts of interest in this paper.

\section{REFERÊNCIAS}

1. American Heart Association. Heart Disease and Stroke Statistics-2009.

2. BLOEDON LT, SZAPARY PO. Flaxseed and cardiovascular risk. Nutr Rev, 2004, 62(1):18-27.

3. BAYINDIR O, OZMEN D, MUTAF I. et al. Comparison of the effects of dietary saturated, mono and n-6 polyunsaturated fatty acids on blood lipi profile, oxidant stress, prostanoid synthesis and aortic histology in rabbits. Ann Nutr Metab, 2002, 46:222-228.

4. BRASIL. Procedimento e métodos de eutanásia em animais. Resolução número 714 de 20 de Junho de 2002. Conselho Federal de Medicina Veterinária - CFMV - 23 de Outubro de 1968.

5. CASTRO PSG, OLIVEIRA FLC. Prevention of atherosclerosis and drug treatment of high-risk lipid abnormalities in children and adolescents. J Pediatr (Rio J), 2009, 85 (1): 6-14.

6. CUNNANE SC, GANGULI S, MENARD C, et al. High alpha-linolenic acid flaxseed (Linum usitatissimum): some nutritional properties in humans. Br J Nutr 1993, 69(2):443-53.

7. DORNAS WC, OLIVEIRA TT, FRANKLIN AUGUSTO LE, ET AL. Aterosclerose Experimental em Coelhos. Arq Bras Cardiol 95(2): 272-278, 2010.

8. DUPASQUIER CH, WEBER AM, ANDER BP. ET AL. Effects of dietary flaxseed on vascular contractile function and atherosclerosis during prolonged hypercholesterolemia in rabbits. Am J Physiolol Heart Circ Physiolol, 2006, 291:H2987- H2996.

9. DUPASQUIER CM, DIBROV E, KNEESH AL. et al. Dietary flaxseed inhibits atherosclerosis in the LDL receptor - deficient mouse in a part through antiproliferative and anti inflammatory actions. Am J Physiol Heart Cir Physiol, 2007, 293(4):H2394-402.

10. FALUDI AA, IZAR MCO, SARAIVA JFK et al. Update of the brazilian director of dislipidemias and prevention of aterosclerosis - 2017. Arq Bras Cardiol. Volume 109, No. 1, August, 2017.

11. HASLER CM, BLOCH AS, THOMSON CA, ET AL. Position of the American Dietetic Association: Functional Foods. J. Am Diet Assoc, 2004,104(5):814-26, 
12. JALDIN RG, FILHO HAF, SEQUEIRA JL. et al. O processo aterosclerótico em artérias de coelhos submetidos a dieta suplementada com gema de ovo: modelo experimental de baixo custo. J Vasc Bras, 2006, 5(4):247-56.

13. JENKIS DJA, KENDALL CWC, MARCHIE, A. et al. Dose response of almonds on coronary heart disease risk factors : blood lipids, oxidized low - density lipoproteins, lipoprotein(a), homocysteine, and pulmonary nitric oxide: a randomized, controlled, crossover trial. Circulation, 2002.106:1327-1332.

14. KRIS-ENTHERTON PM, HARRIS WS, APPEL LJ. Fish consumption, fish oil, omega-3 fatty acids, and cardiovascular disease. Circulation 2002,106:2747-2757.

15. KRALOVA LI, SUCHANEK P, KOVAR J, et al. Replacement of dietary saturated FAs by PUFAs in diet and reverse cholesterol transport. J Lipid Res, 2008, 49:2414-8.

16. LEE J, PARK Y, KOO SI. ATP-binding cassette transporter A1 and HDL metabolism: effects of fatty acids. J Nutr Biochem, 2012, 23:1-7.

17. LUCAS EA, MAHAJAN SS, SOUNG DY, ET.AL. Flaxseed but Not Flaxseed Oil Prevented the Rise in Serum Cholesterol Due to Ovariectomy in the Golden Syrian Hamsters. J Med Food 2011, 14(3): 261-267.

18. MANDASESCU S, MOCANU V, DASCALITA AM. et al. Flaxseed supplementation in hyperlipidemic patients. Rev Med Chir Soc Med Nat lasi, 2005,109(3):502-6.

19. MARQUES AC, HAUTRIVE TP, MOURA GB, et.al. Effect of flaxseed (Linum usitatissimum L.) prepared by different methods on the biological response of rats. Rev Nutr, 2011, 24(1):131-141.

20. PRASAD K. Dietary flaxseed in prevention of hypercholesterolemic atherosclerosis. Atherosclerosis 132:69-76, 1997.

21. PRASAD K, MANTHA SV, MUIR AD, ET.AL. Reduction of hypercholesterolemic atherosclerosis by CDCflaxseed with very low a-linolenic acid. Atherosclerosis 1998, 136(2): 367-375.

22. PRASAD K. Reduction of serum cholesterol and hypercholesterolemic atherosclerosis in rabbits by secoisolariciresinol diglucoside isolated from flaxseed. Circulation 99(10):1355-62, 1999.

23. PRASAD K. Flaxseed and Cardiovascular Health. J Cardiovasc Pharmacol, 2009, 54(5): 369-77.

24. PRIM CR, BARONCINI LA, PRÉCOMA LB, ET.Al. Effects of linseed consumption for a short period of time on lipid profile and atherosclerotic lesions in rabbits fed a hypercholesterolaemic diet. Br J Nutr, 2012,107(5):660 4.

25. RATNAYAKE WMN, BEHRENS W, FISCHER P. Chemical and nutritional studies of flaxseed (variety Linott) in rats. J Nutr Biochem 1992, 3:232-240.

26. STARY HC, BLANKENHORN DH, CHANDLER AB. et al. A definition of the intima of human arteries and of its atherosclerosis - prone regions. A report from the Committee on Vascular Lesions of the Council on Arteriosclerosis, Americam Heart Association. Circulation 1992, 85(1):391-405.

27. SCHOENHAGEN P, TUZCU MS. Methods imaging of atherosclerosis in progression / regression trials: surrogate marker or direct window into the atherosclerotic disease process ?. Arq Bras Cardiol, 2008,91 (6): 418-31.

28. STUGLIN C, PRASAD K. Effect of flaxseed consumption on blood pressure, serum lipids, hemopoietic system and liver and kidney enzymes in healthy humans. J Cardiovasc Pharmacol Ther, 2005,10(1):23-7.

29. ZHAO G, ETHERTON TD, MARTIN KR. et al. Dietary alpha - linolenic acid reduce inflammatory and lipid cardiovascular risk factors in hypercholesterolemic men and women. J Nutr, 2004.134:2991-7.

30. WORLD HEALTH ORGANIZATION, WHO publishes the top ten causes of death worldwide, 2011. 